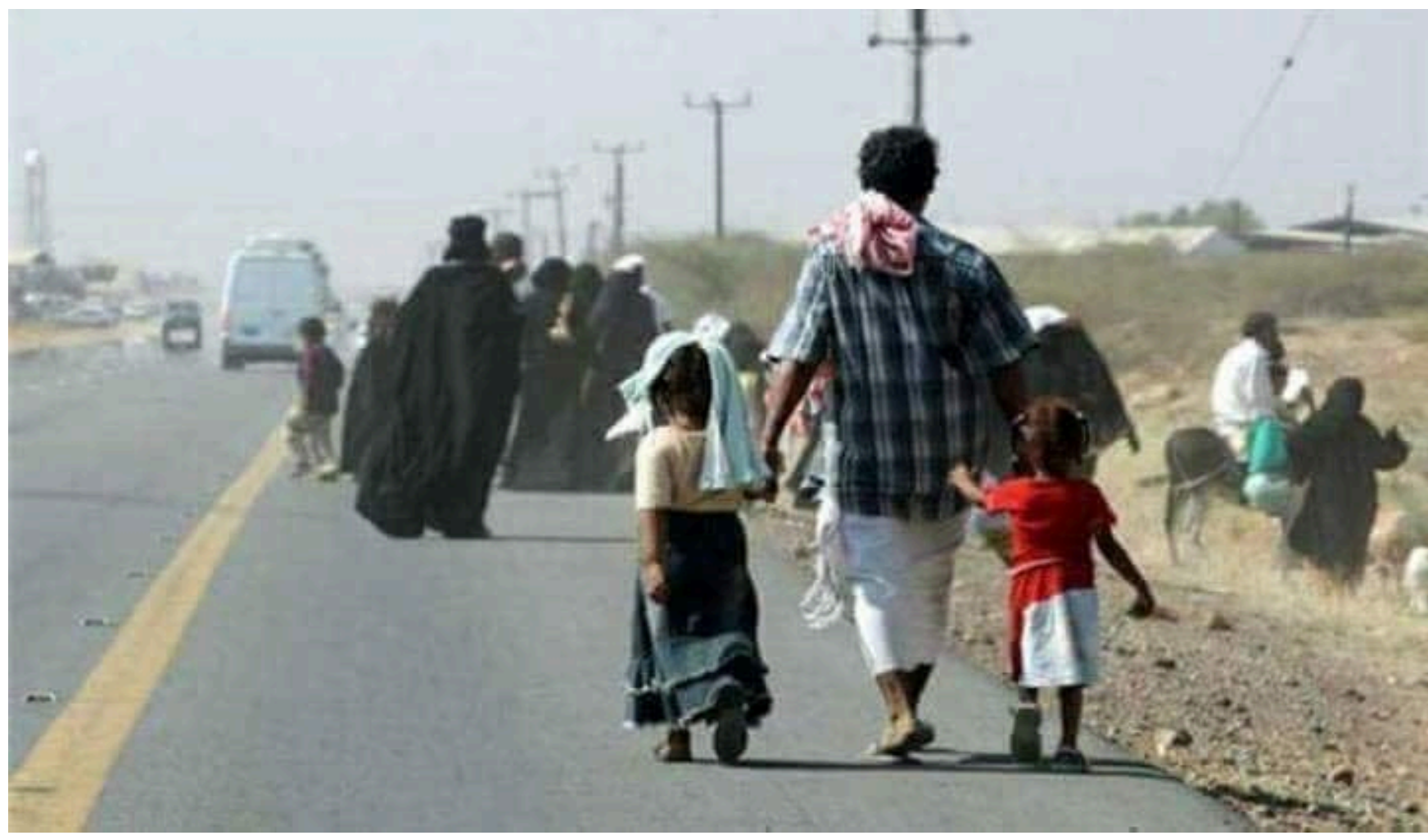

Civilians flee Hudaydah as fighting escalates. Photo: Oxfam.

\title{
THE WORLD MUST BACK PEACE, NOT WAR, TO PUT AN END TO CIVILIAN SUFFERING IN YEMEN
}

\section{As the Hudaydah offensive moves closer to the city and sea port, conditions for civilians are rapidly deteriorating}

Hudaydah's residents are already some of the worst affected in the country by hunger and malnutrition. They now face a rapidly deteriorating humanitarian situation, despite a reported pause in the military advance to the sea port and city, and a recent reduction in the fighting. Most areas have no electricity. Whole neighbourhoods have no water, as pipes have been damaged - raising the fear that cholera could once again grip the city. Dozens of businesses have closed, including those providing milk, oil, margarine and cereals. Thousands have fled their homes because they fear a street war like in Taiz. While all parties fighting refuse to compromise, Yemen's civilians are paying the price. As the Hudaydah offensive moves closer to the sea port and city, world leaders have a choice to put their full backing behind peace to bring an end to this crisis, or oversee a potential humanitarian catastrophe. 


\section{HUDAYDAH OFFENSIVE MOVES CLOSER TO CITY AND SEA PORT}

Despite a reported pause in the military advance to the sea port and city, ${ }^{1}$ fighting continues to take place on the ground at reduced intensity. Government-aligned forces backed by the UAE- and Saudi-led coalition continue the offensive on Hudaydah after their capture of the city's airport, albeit with less ferocity than in previous weeks. Troop movements are coming closer to the sea port and the edges of the city but face resistance from the Houthis, who are reported to have deployed forces, and are using snipers as well as laying trenches and landmines to thwart the advance of the coalition. ${ }^{2}$

The situation remains volatile, and there are continued reports of fighting along the coastal road leading from the airport to the sea port where the fish market is located, and close to the city's university. Intermittent shelling and airstrikes have been reported and a number of roads, mostly in the city, remain closed to civilians. Coalitionbacked forces inside the city are reportedly being reinforced and are receiving military equipment and trying to clear key areas of Houthi fighters. ${ }^{3}$

Displacement continues as people flee to other areas, or out of the city in search of safety due to fear of an imminent attack. ${ }^{4}$ Reports suggest some people are having to take perilous journeys over mountains and valleys, travelling for up to two days to make the journey outside the city limits, which normally takes two hours. The threat of mines also poses a risk to internally displaced persons (IDPs) along the way. ${ }^{5}$ Although overall figures on displacement are not yet clear, at least 6,000 families have been displaced from their homes so far. ${ }^{6}$ Civilian casualties continue to be reported. Coalition airstrikes are reported to have hit a bus carrying displaced people fleeing Hudaydah. ${ }^{7}$

Hudaydah is one of the worst-affected governorates in Yemen when it comes to food shortages and malnutrition. Last year it was one step away from famine, ${ }^{8}$ and it is still experiencing crisis levels of food insecurity. ${ }^{9}$ Twentyfive percent of children in Hudaydah governorate are suffering from malnutrition. ${ }^{10}$ With the disruption to nutritional support from aid agencies, the lives of nearly 100,000 children could be at immediate risk. ${ }^{11}$ Hudaydah was also at the epicentre of last year's cholera emergency.

Information received by Oxfam from eyewitnesses and people on the ground shows a rapidly deteriorating humanitarian situation in the city, and fear and panic among the civilian population about an imminent attack.

'This is the first time we hear the clashes so clearly, we can hear the sound of artillery and automatic weapon fire.' - Resident from Amin Mokbel neighbourhood, where fighting has recently taken place.

\section{PREPARATIONS FOR GROUND WAR LEAD TO FEARS FOR CIVILIAN SAFETY}

Inside Hudaydah city, Houthi fighters are reported to be blocking many streets with sandbags, including streets leading to the port, and are building trenches in preparation for street battles. Some neighbourhoods are without water supplies as the water and sewage network was damaged when the trenches were being dug. Reports point to the Houthis deploying snipers, setting up new check points, locating themselves in residential areas, occupying some public facilities and positioning themselves in civilian buildings, giving rise to very real fears that this will lead to civilians being used as human shields. ${ }^{12}$ 
As well as preparations for street battles, the city streets are increasingly becoming empty of people and activity. There is little to no traffic in most parts of the city, very little public transport or taxis operating, and fuel stations are closed, or open for only a few hours a day.

\section{Yasser, a resident of Hudaydah, said, he is afraid 'the conflict will turn into a street war just like Taiz} city'.

His fear reflects a worst-case scenario that could see Hudaydah under siege like Taiz, with 600,000 people trapped inside the city, used as human shields or caught up in the crossfire, as fighting rages on the streets and air strikes are launched on the city. Previous experience of street battles in Aden, ${ }^{13}$ where it took two months for the UAE to take control of the city, saw high levels of civilian casualties, destruction of the city's infrastructure, and disruption to public services. All of this signals the dangers of a full-on offensive inside the city of Hudaydah, and the importance of avoiding this to protect civilians.

\section{HUMANITARIAN IMPACTS OF THE CURRENT ESCALATION}

\section{DISPLACEMENT ON THE RISE}

People continue to flee out of fear. Many of those who are leaving live close to areas where fighting is taking place. Others are leaving because they fear that military operations will escalate. It is taking time to verify official numbers of people displaced. They are being forcibly displaced within their own districts inside the city, or to neighbouring governorates including Hajja, Sana'a, Dhamar and Ibb. Some are leaving using their own vehicles, and others public transport when it is available. The cost of public transport is extremely high, with many poor people unable to pay these prices. It costs $\$ 150$ for a family of six to travel to the capital Sana'a or Taiz city, or $\$ 70$ to flee to inner districts inside Hudaydah. ${ }^{14}$ Many of those who manage to flee to other cities are unable to afford accommodation or the high cost of rent as properties are in short supply, and because landlords are hiking up prices. It can cost $\$ 500$ per month to rent accommodation and feed a family in Sana'a. ${ }^{15}$ People displaced inside the city are sheltering in schools. Although they are receiving some assistance from humanitarian agencies, there are difficulties getting humanitarian goods into the city, and access to warehouses has become difficult due to ongoing fighting and blockage of some roads. Access to IDPs in Al Tuhayata, Al Durayhimi and Al Garrahi districts is a challenge due to ongoing hostilities in those areas. ${ }^{16}$

\section{Omar, a resident of the city, said he is seeing continuous waves of people leaving in private cars or public buses. Families are taking little with them, although he has seen people carrying gas canisters, and bags of food. He even saw one family take their cooker.}

Ahmed, 30, is the sole breadwinner for two families and used to work on a palm farm. He and his family, along with four other families, fled Hudaydah after clashes between the government forces and Houthis reached his village. During the heavy clashes, shrapnel hit his house, forcing them to leave. After walking for 10 hours through a sandstorm and with nothing to eat or drink, they found safety in a village outside of the city in Bait Al-Faqih district. They received some assistance from humanitarian agencies when they arrived. Although his family managed to get to safety, he said others were not so lucky and faced death because of mines laid on the roads. 


\section{THE DANGEROUS THREAT OF CHOLERA}

Electricity is unavailable in many areas of Hudaydah city, and water shortages have been reported due to recent damage to supply pipes, which affects many areas of the city, including entire neighbourhoods. ${ }^{17}$ Sanitation problems have also been reported in some IDP sites, which could trigger a cholera outbreak.

The damage to the water system has pushed some residents of the southern and western neighbourhoods of the city to leave their homes in search of water.

\section{Hind, a nurse at a private hospital, had to move her family out of their home to another area in the city after five days with no water and with little hope that the water network would be fixed.}

Hudaydah was one of the epicentres of last year's cholera outbreak, one of the worst in modern history. ${ }^{18}$ If the water system in just one neighbourhood breaks down, this means that because of damage to the sewage system as a result of the recently-dug trenches and a lack of immediate repairs to address the situation, cholera could spread with lightning speed. The repair of the water and sewage system in the city is therefore a critical priority.

\section{CLOSURE OF FACTORIES AND BUSINESSES, AND DISRUPTION TO MARKETS}

Ongoing clashes in Hudaydah city have destroyed commercial and public service facilities, including Al Mukhtar hospital, which has been partially destroyed.

Oxfam has heard from its sources on the ground in Hudaydah that dozens of factories and commercial businesses including mills have stopped production because of fighting close by, and/or reportedly because workers are too scared to turn up for work. Of note is that it is not just small businesses, but also large-scale commercial suppliers, who are closing their doors. The factories which have closed were producing goods such as margarine, milk, oils, cereals and other foods needed by residents. Some factories located close to the fighting have had to empty goods into trucks and move them to other locations out fear the goods will be destroyed or looted. Most shops and shopping malls in the city are also closed, with some fearing looting, and others closing because of the insecurity. Some shops open for a few hours a day, with owners too scared to stay open all day, and also to ensure their limited stocks last as long as possible. Traders and businesspeople are also leaving the city, disrupting people's access to markets, food and essential goods. ${ }^{19}$

Long lines have been forming at fuel stations, with cars queueing down the street and people desperate to fill up with petrol. With limited fuel available even in the parallel markets, those who can afford to pay the hefty prices are stocking up in anticipation of a military escalation and protracted street war. Some traders are also reportedly hoarding fuel and pushing up prices, further reflecting that there is still profit to be made by those with few scruples.

Although Hudaydah port is still reportedly operating,$^{20}$ complicated checking procedures and delays means getting goods into the country is already a major problem. ${ }^{21} \mathrm{Al}$ Hudaydah is the most important point of entry for the food and basic supplies needed for 20 million Yemenis to prevent famine and the recurrence of a cholera 
epidemic. Any disruption or attack on the port which results in the cessation of imports means cutting off the lifeline not just for the people of Hudaydah, but also for a country with 8.4 million people already on the verge of starvation. ${ }^{22}$ This is unjustifiable and could constitute a war crime.

\section{SHORTAGES OF ESSENTIAL SUPPLIES, AND THE SKYROCKETING PRICE OF FOOD}

Civilians can still move in some parts of the city. Movement in the downtown neighbourhoods is possible, with a few shops and restaurants still open, but the southern and eastern neighbourhoods lie empty and abandoned. With shops, bakeries and restaurants remaining closed, ${ }^{23}$ this is limiting the availability of supplies in the market. According to the Food Security and Agriculture Cluster, part of the UN coordination system, there is a shortage of basic commodities including wheat flour, vegetable oil and cooking gas in markets. As of 24 June, where available, prices of wheat and vegetable oil have increased by about 30 percent and that of cooking gas by 52 percent. ${ }^{24}$ Similar price hikes have also been reported by Oxfam sources on the ground, including a 350 percent rise in the price of a sack of rice (see Table 1). People with some cash are panic buying, purchasing goods in large quantities to stockpile. Money exchange shops where people can access cash from remittances have closed. The limited access to cash and reported price rises are a threat to people's food security. ${ }^{25}$

Traders are complaining that retailers are hiking up prices to make a profit, and this in turn is pushing up prices for civilians. After three years of war most Yemenis struggle to afford basic amenities even under normal circumstances. These extra price hikes associated with the military escalation in Hudaydah are likely to push prices far beyond the reach of many vulnerable Yemenis.

\section{A local retail trader said he bought his goods from the wholesale traders who were behaving greedily by putting up prices for retailers and making it difficult for retailers like himself to make a profit.}

Another retail trader said that most of the wholesale traders bought their goods before Ramadan, and expressed his outrage at them exploiting the crisis to raise prices.

Table 1: Price increases for selected staple foodstuffs

\begin{tabular}{|l|l|l|l|}
\hline Food items & May price in Yemeni rial & $\begin{array}{l}\text { Current price in Yemeni } \\
\text { rial }\end{array}$ & Price rise in Yemeni rial \\
\hline Sack of flour, $50 \mathrm{~kg}$ & 9,600 & 11,900 & 2,300 \\
\hline Sack of rice, $50 \mathrm{~kg}$ & 28,000 & 38,700 & 10,700 \\
\hline Sack of sugar, $50 \mathrm{~kg}$ & 10,300 & 13,250 & 2,950 \\
\hline Sack of wheat, 50kg & 8,000 & 12,000 & 4,000 \\
\hline Cooking oil, 9L & 4,500 & 6,300 & 1,800 \\
\hline Nido baby milk, 5kg & 9,150 & 10,900 & 1,750 \\
\hline
\end{tabular}

Source: Information collected by Oxfam sources on the ground, 21 June 2018. One Yemeni rial = 0.0040 USD on 3 July 2018. 


\section{SHUTTLE DIPLOMACY YET TO DELIVER RESULTS}

On the political track, the UN Special Envoy for Yemen, Martin Griffiths, continues his shuttle diplomacy. He has met with the EU Foreign Affairs Representative Federica Mogherini and EU Foreign Ministers, and travelled to Sana'a and Aden ${ }^{26}$ to meet with the Houthis and President Hadi. His efforts are focused on securing a political deal to avert an assault on the port and Hudaydah city, in order prevent the exacerbation of the humanitarian crisis, as well as to obtain buy-in for his proposed peace deal and resumption of peace talks. ${ }^{27}$

Although the coalition announced a pause in its advance and has reportedly delayed a full-scale military escalation targeting the city and port, ${ }^{28}$ the fighting goes on and conditions for people in Hudaydah continue to deteriorate. Any pause in the fighting, although welcome, cannot substitute for a sustainable ceasefire in Hudaydah and other parts of the country. The political positions of the parties to the conflict remain at a stalemate, with the coalition demanding an unconditional withdrawal by Houthi forces from the sea port and Hudaydah city. The Houthis are reportedly willing to hand over management of the port to the UN, but they are not willing to withdraw from the city or lay down their arms. ${ }^{29}$

While those involved in the fighting refuse to compromise it is Yemeni civilians who continue to pay the price. Stopping military operations and returning to the political track remains an urgent priority to put an end to the suffering of Yemenis wearied by three years of war. The stakes and human costs of a further military assault on Hudaydah city and sea port are high and unjustifiable. It is time for the UN and international community to put their full weight behind a renewed push for peace in Yemen.

\section{RECOMMENDATIONS}

\section{To the UN and Member States:}

- The UN Security Council and the coalition's international partners should demand an immediate cessation of the assault, before it continues to Hudaydah city or sea port, and an unconditional ceasefire by the coalition and all Yemeni forces, including Houthi forces.

- Every relevant government should immediately suspend arms transfers to parties to the conflict in Yemen, and not grant future arms transfer licenses until there is no longer a clear risk that arms could be used to commit serious violations or grave breaches of international human rights or humanitarian law.

- The UN and Members States must apply pressure on parties to the conflict, the Houthis, the Yemeni Government, the Saudi- and UAE-led coalition and other armed actors to abide by their obligations under international law and do everything possible to protect civilians and civilian infrastructure. All parties to the conflict must ensure that people who want to leave areas of fighting to seek safety can do so, and have access to the assistance they need to survive.

- The UN and donor governments should support the urgent rehabilitation of the water and sewage networks in Hudaydah to avoid the danger of a deadly cholera outbreak.

- The UN Security Council and the international community should support an inclusive peace process, engaging Yemeni women, youth and civil society, and reflecting the international community's commitments to women, peace and security.

- The UN Security Council and the international community should ensure that Hudaydah and Saleef ports remain fully operational, and key routes remain open, so that that food, fuel, medicine and other essential goods can move freely across the country. 
- Allies of the Saudi- and UAE-led coalition members should leverage their relationships to avoid the use of any explosive weapons in populated areas in Hudaydah.

- The UN Security Council should urgently hold an open meeting, in which all governments' statements can be freely reported, to collectively demand the implementation of the above recommendations. Members of the coalition and its international partners, including the US, UK and France, should not hide from public scrutiny behind closed doors at the Council, which has failed the people of Yemen for more than three years.

\section{The Houthis, the Yemeni government and Saudi- and UAE-led coalition should:}

- Stop the violence and fighting in and around Hudaydah, agree to an immediate countrywide ceasefire, return to negotiations and back an inclusive political process which includes Yemeni women, youth and civil society, to bring an end to the conflict and suffering.

\section{Respect international law and uphold the rules of war.}

- Protect civilian men, women and children.

- Protect civilian infrastructure such as schools, hospitals and homes.

- Allow safe passage for those who want to escape the fighting.

- Allow the unimpeded movement of vital humanitarian aid such as food, water and medical supplies, and remove bureaucratic impediments and other obstacles to the delivery of aid.

- Facilitate civilian access to humanitarian aid.

- Do not seek shelter in civilian buildings or use civilians as human shields.

- Respect the principle of proportionality. Stop military action that has a disproportionate impact on civilians and take every action to mitigate the devastating impacts of the fighting on civilians.

\section{Protect Hudaydah's vital infrastructure.}

- This includes water, sewage and electricity networks.

- Avoid destruction of roads, bridges or any other civilian infrastructure vital for civilians to escape the fighting, or for humanitarian supplies to move freely.

\section{Protect Yemen's lifeline Hudaydah sea port.}

- Keep Hudaydah port open and undamaged to allow vital humanitarian and commercial supplies of food, fuel and other vital goods into the country.

- Avoid destruction of the port's infrastructure.

- Allow the UN to take over supervision of the port. 


\section{NOTES}

1 Anwar Gargash, Foreign Minister, UAE. 1 July 2017. https://twitter.com/anwargargash?lang=en

2 Independent. (30 June 2018). Battle for Hudaydah: Fears Grow for Yemeni Civilians As Negotiations Between the Coalition and Houthi's falter: https://www.independent.co.uk/news/world/middle-east/yemen-Hudaydahh-latest-saudi-arabia-uaecoalition-airstrikes-houthis-a8421651.html

3 The New Arab. (22 June 2018). Army reinforcements roll in to Yemen's embattled Hudaydah: https://www.alaraby.co.uk/english/news/2018/6/22/army-reinforcements-roll-into-yemens-embattled-Hudaydahh

4 OCHA. (24 June 2018). YEMEN: Al Hudaydah Update. Situation Report No. 5. https://reliefweb.int/sites/reliefweb.int/files/resources/20180624 Al\%20Hudayday Update Issue 5 v3.pdf

5 Paton Walsh, Nick. (27 June 2018). As fighting edges closer to Hudaydah, the biggest losers are Yemeni civilians. https://edition.cnn.com/2018/06/27/middleeast/yemen-Hudaydahh-port-int//index.html

6 OCHA. (27 June 2018). YEMEN: Al Hudaydah Update. Situation Report No. 6. https://reliefweb.int/sites/reliefweb.int/files/resources/20180627 Al\%20Hudayday\%20Update Issue\%206.pdf

7 Middle East Eye. (26 June 2018). Saudi-led coalition airstrike kills nine civilians fleeing Hudaydah: Reports. http://www.middleeasteye.net/news/yemen-war-saudi-bombing-campaign-kills-nine-civilians-fleeing-Hudaydah1317089302; and OCHA. (27 June 2018). YEMEN: Al Hudaydah Update. Situation Report No. 6. Ibid.

8 FAO. (2017). IPC Map of Yemen - March-July 2017. http://www.fao.org/emergencies/resources/maps/detail/en/c/847475/

9 FEWS NET. (April 2018). Yemen Food Security Outlook Update. https://reliefweb.int/sites/reliefweb.int/files/resources/YEMEN Food Security Outlook Update April2018 0.pdf

10 WFP (15 March 2017). Yemen Needs Urgent Food Assistance to Prevent Famine: https://reliefweb.int/report/yemen/yemen-needs-urgent-assistance-prevent-famine; and WHO, Situation Report \# 1. 17 June - 23 June 2018. https://reliefweb.int/sites/reliefweb.int/files/resources/WHO Sitrep_Al_Hudaydah_no.1_24.06.2018_Cleared_pdf

11 OCHA. (21 June 2018). Hundreds of thousands of civilians in Hudaydah are at grave risk. https://reliefweb.int/report/yemen/hundreds-thousands-civilians-Hudaydahh-are-grave-risk-enar

12 Middle East Eye (28 June 2018). In Yemen's Hudaydah, Houthis dig in for protracted street fighting: http://www.middleeasteye.net/news/yemen-s-Hudaydahh-houthis-dig-protracted-street-fighting-1450540011; and Human Rights Watch. (15 June 2018). Yemen: Key Concerns for Hudaydah Battle: https://www.hrw.org/news/2018/06/15/yemenkey-concerns-Hudaydah-battle

13 Al Jazeera Report. (8 April 2015). Yemen's Houthis Battle in Central Aden, First Medical Aid Arrives: https://uk.reuters.com/article/us-yemen-security/yemens-houthis-battle-in-central-aden-first-medical-aid-arrivesidUKKBNOMY1TL20150408

14 Oxfam source in Hudaydah.

15 Oxfam source in Hudaydah.

16 OCHA. (22 June 2018). YEMEN: Al Hudaydah Update. Situation Report No. 4. https://reliefweb.int/sites/reliefweb.int/files/resources/20180621 Al Hudayday Update Issue 4 v4.pdf

17 Neighbourhoods affected by the cuts to the water and sewage system include Al Shuhada, Al Salakhana in Hali district and the neighbourhoods of Rabssa and Galil in Hawk district.

18 Alles, Larissa. (16 August 2017). Yemen. Catastrophic Cholera Crisis. https://policypractice.oxfam.org.uk/publications/yemen-catastrophic-cholera-crisis-620328

19 Oxfam source in Hudaydah.

20 OCHA. (24 June 2018). YEMEN: Al Hudaydah Update. Situation Report No. 5. Op. cit.

21 Alles, Larissa. (20 December 2017). Missiles and Food: Yemen's man-made food security crisis. https://policypractice.oxfam.org.uk/publications/missiles-and-food-yemens-man-made-food-security-crisis-620388

22 Mark Lowcock, Under Secretary General OCHA Statement, (24 May 2018): https://reliefweb.int/report/yemen/undersecretary-general-humanitarian-affairs-and-emergency-relief-coordinator-mark-6

23 OCHA. (27 June 2018). YEMEN: Al Hudaydah Update. Situation Report No. 6. Op. cit.

24 OCHA. (24 June 2018). YEMEN: Al Hudaydah Update. Situation Report No. 5. Op. cit. 
25 OCHA. (27 June 2018). YEMEN: Al Hudaydah Update. Situation Report No. 6. Op. cit.

26 New York Times, (1 July 2018), In Yemen, A Pause In the Fighting Raises Hopes For Peace Talks: https://www.nytimes.com/2018/07/01/world/middleeast/yemen-alhudaydah-united-arab-emirates.html

27 Strobel, Warren et al. (7 June 2018). Yemen Peace Plan sees ceasefire, Houthis abandoning missiles: https://uk.reuters.com/article/uk-un-yemen-exclusive/exclusiveyemen-peace-plan-sees-ceasefire-houthis-abandoning-missiles-idUKKCN1J22YY

28 Alyemany, Khaled Hussein. (27 June 2018). Statement after the meeting of President Hadi and the UN Special Envoy for Yemen.

https://twitter.com/YemenEmbassy DC/status/1012006530856693760 
(C) Oxfam International July 2018

This paper was written by Sultana Begum. Oxfam acknowledges the assistance of Dina El Mamoun in its production. It is part of a series of papers written to inform public debate on development and humanitarian policy issues.

For further information on the issues raised in this paper please email advocacy@oxfaminternational.org

This publication is copyright but the text may be used free of charge for the purposes of advocacy, campaigning, education, and research, provided that the source is acknowledged in full. The copyright holder requests that all such use be registered with them for impact assessment purposes. For copying in any other circumstances, or for re-use in other publications, or for translation or adaptation, permission must be secured and a fee may be charged. Email policyandpractice@oxfam.org.uk.

The information in this publication is correct at the time of going to press.

Published by Oxfam GB for Oxfam International under

ISBN 978-1-78748-297-5 in July 2018.

DOI: $10.21201 / 2018.2975$

Oxfam GB, Oxfam House, John Smith Drive, Cowley, Oxford, OX4 2JY, UK.

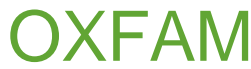

Oxfam is an international confederation of 20 organizations networked together in more than 90 countries, as part of a global movement for change, to build a future free from the injustice of poverty. Please write to any of the agencies for further information, or visit www.oxfam.org
Oxfam America (www.oxfamamerica.org)
Oxfam Australia (www.oxfam.org.au)
Oxfam India (www.oxfamindia.org)
Oxfam-in-Belgium (www.oxfamsol.be)
Oxfam Intermón (Spain) (www.oxfamintermon.org)
Oxfam Brasil (www.oxfam.org.br)
Oxfam Canada (www.oxfam.ca)
Oxfam Ireland (www.oxfamireland.org)
Oxfam Italy (www.oxfamitalia.org)
Oxfam Japan (www.oxfam.jp)
Oxfam France (www.oxfamfrance.org)
Oxfam Mexico (www.oxfammexico.org)
Oxfam Germany (www.oxfam.de)
Oxfam New Zealand (www.oxfam.org.nz)
Oxfam GB (www.oxfam.org.uk)
Oxfam Hong Kong (www.oxfam.org.hk)
Oxfam Novib (Netherlands) (www.oxfamnovib.nl)
Oxfam Québec (www.oxfam.qc.ca)
Oxfam IBIS (Denmark) (http://oxfamibis.dk/)
Oxfam South Africa (www.oxfam.org.za) 